\title{
RESEARCH ON KNEE SPORTS INJURY CLASSIFICATION BASED ON MEDICAL IMAGES AND KWON3D SOFTWARE
}

\author{
PESQUISA SOBRE CLASSIFICAÇÃO DE LESÕES ESPORTIVAS NO JOELHO COM BASE EM IMAGENS \\ MÉDICASESOFTWARE KWON3D \\ INVESTIGACIÓN SOBRE CLASIFICACIÓN DE LESIONES DEPORTIVAS DE RODILLA BASADA EN IMÁGENES \\ MÉDICAS Y SOFTWARE KWON3D
}

\section{Nai Liu' (ID \\ (Physical Education Professional) Bichuan Liư (D) \\ (Physical Education Professional)}

1. Education Department, Jiangxi University of traditional Chinese Medicine, Nanchang, China. 2. Physical Education Department, Jiangxi University of traditional Chinese Medicine, Nanchang, China.

\section{Correspondence:}

Physical Education Department of Jiangxi University of traditional Chinese Medicine, Nanchang 330000, China.

liubichuanbcl@yeah.net

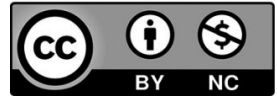

\begin{abstract}
Introduction: The integrity of articular cartilage determines the functional state of the joint. In recent years, the development of MRI sequences of various articular cartilage has become the focus of many research topics. Objective: The accuracy of diagnosis of knee cartilage injury caused by motion injury was studied retrospectively by meta-three-dimensional software. Methods: Forty-six knee joints of 45 patients with sports injuries, multi-sequence MRI was performed before surgery, including conventional knee MRI (SET1WI, FSEPD/T2WI), 3D SPGR, and 3D FIESTA sequences. Results: According to the operation results, the sensitivity, specificity, positive predictive value, and negative predictive value of 3D SPGR combined with conventional MRI sequence evaluation of cartilage damage are the highest, $73 \%, 98 \%, 95 \%$, and $90 \%$. Conclusions: 3D SPGR combined with conventional MRI sequences can improve accurate evaluation and diagnosis of cartilage disease over a reasonable scan time. Level of evidence Il; Therapeutic studies - investigation of treatment results.
\end{abstract}

Keywords: Wounds and injuries; Knee; Diagnostic imaging.

\section{RESUMO}

Introdução: A integridade da cartilagem articular determina o estado funcional da articulação. Nos últimos anos, o desenvolvimento de sequências de ressonância magnética de várias cartilagens articulares se tornou o foco de muitos tópicos de pesquisa. Objetivo: A precisão do diagnóstico de lesão da cartilagem do joelho causada por lesão de movimento foi estudada retrospectivamente por software meta-tridimensional. Métodos: Quarenta e seis articulações de joelho de 45 pacientes com lesões esportivas, várias sequências de ressonância magnética foram realizadas antes da cirurgia, incluindo ressonância magnética de joelho convencional (SETIWI, FSEPD/T2WI), 3D SPGR e sequências 3D FIESTA. Resultados: De acordo com os resultados da operação, a sensibilidade, especificidade, valor preditivo positivo e valor preditivo negativo de 3D SPGR combinado com avaliação de sequência de ressonância magnética convencional de danos na cartilagem são os mais altos, 73\%, 98\%, 95\% e 90\%. Conclusões: 3D SPGR combinado com sequências convencionais de ressonância magnética pode melhorar a avaliação precisa e diagnóstico de doença da cartilagem em um tempo de varredura razoável. Nível de evidência Il; Estudos terapêuticos- investigação dos resultados do tratamento.

Descritores: Ferimentos elesões; Joelho; Diagnóstico por imagem.

\section{RESUMEN}

Introducción: La integridad del cartílago articular determina el estado funcional de la articulación. En los últimos años, el desarrollo de secuencias de resonancia magnética de varios cartílagos articulares se ha convertido en el foco de muchos temas de investigación. Objetivo : La precisión del diagnóstico de la lesión del cartílago de la rodilla causada por una lesión por movimiento se estudió retrospectivamente mediante un software meta-tridimensional. Métodos: Cuarenta y seis articulaciones de rodilla de 45 pacientes con lesiones deportivas, se realizó una resonancia magnética de secuencia múltiple antes de la cirugía, incluida la resonancia magnética de rodilla convencional (SETTWI, FSEPD/T2WI), secuencias 3D SPGR y 3D FIESTA. Resultados: De acuerdo con los resultados de la operación, la sensibilidad, la especificidad, el valor predictivo positivo y el valor predictivo negativo de 3D SPGR combinados con la evaluación de la secuencia de resonancia magnética convencional del daño del cartílago son los más altos, 73\%, 98\%, 95\% y 90\%. Conclusiones: 3D SPGR combinado con secuencias de resonancia magnética convencionales puede mejorar la evaluación y el diagnóstico precisos de la enfermedad del cartílago en un tiempo de exploración razonable. Nivel de evidencia II; Estudios terapéuticos- investigación de los resultados del tratamiento.

Descriptores: Heridas y lesiones; Rodilla; Diagnóstico por imagen. 


\section{INTRODUCTION}

The integrity of articular cartilage determines the functional state of the joint. A rapid and non-invasive diagnostic technique is needed clinically to assess cartilage conditions.' In recent years, the development of MRI sequences of various articular cartilage has become the focus of many research topics. The purpose of this test is to compare the evaluation differences of several MRI sequences for traumatic knee cartilage injury and use the surgical results as the reference standard.

\section{METHODS}

\section{Case selection}

In this experiment, 46 knee joints of 45 patients were selected. Of the 45 cases, 27 were male and 18 were female. age between 19 and 62 years (mean 31 years), with less than 6 months between motor injury and MRI scans in all cases.

\section{MR scan}

The paper uses GE1.5T superconducting MR (Signa; General Electric Medical Systems, Milwaukee, WI), knee joint coil.

Scan time: coronal T1WI3min34s, coronal or sagittal PD/T2WI scan time is 3min47s, 3D SPGR sequence scan time is $4 \mathrm{~min} 55 \mathrm{~s}-5 \mathrm{~min} 59 \mathrm{~s}, 3 \mathrm{D}$ FIESTA sequence scan time is $4 \mathrm{~min} 41 \mathrm{~s}-5 \mathrm{~min} 17 \mathrm{~s}$.

\section{Image analysis}

Doctors successively evaluated 3D SPGR, 3D FIESTA, and 3D SPGR combined with conventional MRI sequence (SET1WI, FSEPD/ T2WI) images. ${ }^{2}$

The paper is evaluated by the improved Noyes classification system: 0 levels. The signal is standard, and the thickness is uniform; level 1. A local signal is abnormal, and a cartilage surface is not abnormal; Grade 2. Superficial ulcer or fissure, the depth does not exceed $50 \%$ of the full cartilage; grade 3. Deep ulcer or fissure, more than $50 \%$ of cartilage but $<100 \%$; grade 4 . Full-thickness cartilage defects may be accompanied by subchondral bone damage. When cartilage lesions of different degrees exist in the same area simultaneously, the highest level shall prevail.

Forty cases underwent arthroscopic surgery, of which one had both knees. Five cases received open surgery. All operations were performed within seven days after the patient underwent MRI. ${ }^{3}$

We use Kwon3D software to start the sample collection. The shape of a model in the three-dimensional space needs $3 \mathrm{n}$ parameter expressions. The main component. ${ }^{4}$ The calculation steps are as follows: We use the paired points of the sample set to establish the covariance matrix Cov:

$$
\mathrm{Cov}=\frac{1}{\mathrm{P}-1} \sum_{i=1}^{P}\left(S_{i}-\bar{S}\right)\left(S_{i}-\bar{S}\right)^{T}
$$

Among them: $S_{i}=\left(x_{1}, y_{1}, z_{1}, \cdots, x_{n}, y_{n}, z_{n}\right)^{T}, \bar{S}=\frac{1}{P} \sum_{i=1}^{P} S_{i} ; \bar{S}$ is the average model of the training set; solve the eigenvector and eigenvalue $\lambda$ according to the covariance matrix:

$$
\lambda_{1} \geq \lambda_{2} \geq \cdots \lambda_{\mathrm{m}} \geq 0, m=P-1
$$

The geometric deformation characteristics of each model $S_{i}$ in the sample set are expressed as follows:

$$
S_{i}(a)=\bar{S}+\sum_{q=1}^{m} a_{q} \sqrt{\lambda_{q} \phi_{q}}
$$

Among them: $\mathrm{a}$ is the deformation coefficient, and its dimension is consistent with the number of selected eigenvalues, which is much smaller than $3 n$. Usually select the first few eigenvalues whose cumulative value accounts for 95\% of the eigenvalues'sum, as shown in Figure 1.

Two-dimensional fluoroscopy can adopt a single $C$ - arm system or double $C$ - arm system or adopt SHIMADZU a digital X-ray multifunctional perspective photography system for multi-angle imaging. The three-dimensional model has 6 degrees of freedom in space, and six parameters can be used to express ( $x, y, z, a, \beta, \gamma)$. According to the projection system's known parameters, the spatial projection relationship is established, ${ }^{5}$ and the above six parameters can be obtained through optimization calculation. The objective function is defined as follows:

$$
I=\sum_{f=1}^{F} \frac{1}{N_{f}} \sum_{t=1}^{N_{f}} d_{t}^{2}=\sum_{f=1}^{F} \frac{1}{N_{f}} \sum_{t=1}^{N_{f}}\left|g_{t}^{f}-Q^{f}\right|^{2}
$$

Among them: $\mathrm{F}$ is the number of perspective images used; $\mathrm{g}$ is the target contour manually selected in the two-dimensional image before the optimization calculation; $\mathrm{N}$ is the number of points selected at equal intervals on the contour; $d_{t}$ is the selected point to the solution the vertical distance between the outer contours. The three-dimensional model to be registered in the imaging space is projected on the imaging plane through a virtual point ray source. The outer contour $\mathrm{Q}$ is solved by the automatic extraction algorithm of the target contour. ${ }^{6}$

To determine the initial position of the deformable model, we register each model and two-dimensional image in the statistical model training set, optimize and calculate a series of spatial positions, and record the final error $J_{i}$ :

$$
J_{i}=\min _{x, y, z, a, \beta, \gamma} I_{i}
$$

Among them: ${ }^{I_{i}}$ is the objective function established by registering the i-th model and the two-dimensional image in the statistical model training set. Based on this, the initial position matrix is calculated:

$$
M_{4 \times 4}=\left\{\underset{x, y, z, a, \beta, \gamma}{M} \mid \min \left(J_{i}\right), i=1: P\right\}
$$

To reconstruct the personalized target model $S^{\prime}$. The two-dimensional knee joint image used in this study has complex boundary information. ${ }^{7}$ Suppose the boundary information obtained by the image gradient calculation is used to reconstruct the knee joint model.

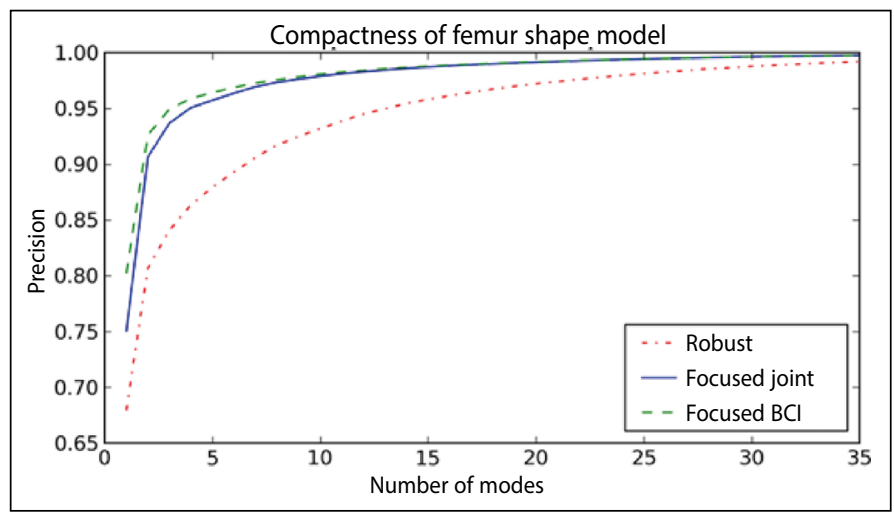

Figure 1. Femoral model eigenvalue distribution. 
Therefore, the paper uses manually selected target contours to control the deformation and establish the objective function $I^{\prime}$ :

$$
I^{\prime}=\sum_{f=1}^{F} \frac{1}{N_{f}} \sum_{t=1}^{N_{f}}\left|g_{f}^{t}-Q_{f}\left(S^{\prime}\right)\right|^{2}
$$

Among them: $S^{\prime}=M \bar{S}+M \sum_{q=1}^{m} a_{q} \sqrt{\lambda_{q}} \phi_{q}, a_{q}$ is the deformation coefficient. Optimize the minimum value $J^{\prime}$ of the objective function:

$$
J^{\prime}=\min _{a_{1}, a_{2}, \cdots, a_{q}} I^{\prime}
$$

We obtain the deformation coefficient through the above calculation, and the calculation is the generated three-dimensional personalized knee joint model of the specific bone (femur, tibia, patella). This study's optimization problems are all nonlinear optimization, using MATLAB's function embedded algorithm: large-scale optimization uses the internal mapping Newton method, and medium-scale optimization uses the sequential quadratic programming method. ${ }^{8}$

\section{Statistical analysis}

The author chose grades 0 and 1 (complete cartilage surface) as harmful and grades 2, 3, and 4 (different degrees of cartilage defects) as positive. The paper calculates the sensitivity, specificity, and accuracy of 3D SPGR, 3D FIESTA, conventional MRI, and 3D SPGR. Simultaneously, the paper uses the Wilson scoring method to calculate the $95 \%$ confidence interval of sensitivity and specificity and uses the McNamara statistical method two-tailed precision table to compare the significant differences in each of the cartilage grading diagnoses sequence of MRI. $P<0.05$ indicates that the difference is statistically significant.

\section{RESULTS}

According to knee arthroscopy results or open surgery, 158 articular cartilage surfaces were standard (grade 0), and 55 cartilage surfaces showed limited softening or discoloration (grade 1). The number of grades 2 , grade 3 , and grade 4 cartilage abnormalities was 47,7 , and 9 . The incidence of cartilage changes was 43\% (118/276), and the incidence of cartilage defects was 23\% (63/276).

The articular cartilage damage was graded through each sequence of images (Figure 2 and Figure 3). In the 3D SPGR sequence, 105 articular surfaces were considered normal (level 0), and 85 at level 1. The number of grades 2, grade 3, and grade 4 were 70, 9, and 7, respectively, and the complete agreement rate with the surgical diagnosis of cartilage damage of each grade was 53\%. In the 3D FIESTA sequence, there are 88 places at level 0, 106 places at level 1,67 places at level 2,6 places at level 3 , and 9 places at level 4 . The complete agreement rate with surgical-grade is 60\%, which is higher than the complete agreement rate of 3D SPGR, but There was no statistically significant difference between the two $(P=0.85)$. The combination of 3D SPGR and conventional MRI sequences determined that the number of grade 0 and grade 1 were 148 and 63, respectively, and the number of grades 2, 3, and 4 were 49, 7 , and 9 , respectively. ${ }^{9}$ The complete agreement rate with the surgical results was the highest (85\%). Still, there was no statistically significant difference in the complete agreement rate with the above two sequences (P values were $0.33,0.86$, respectively) (Table 1 ).

The thesis calculated the sensitivity, specificity, and accuracy of the six knee joint surfaces (Table 2) and the positive and negative predictive values of each MRI technique (Table 3).

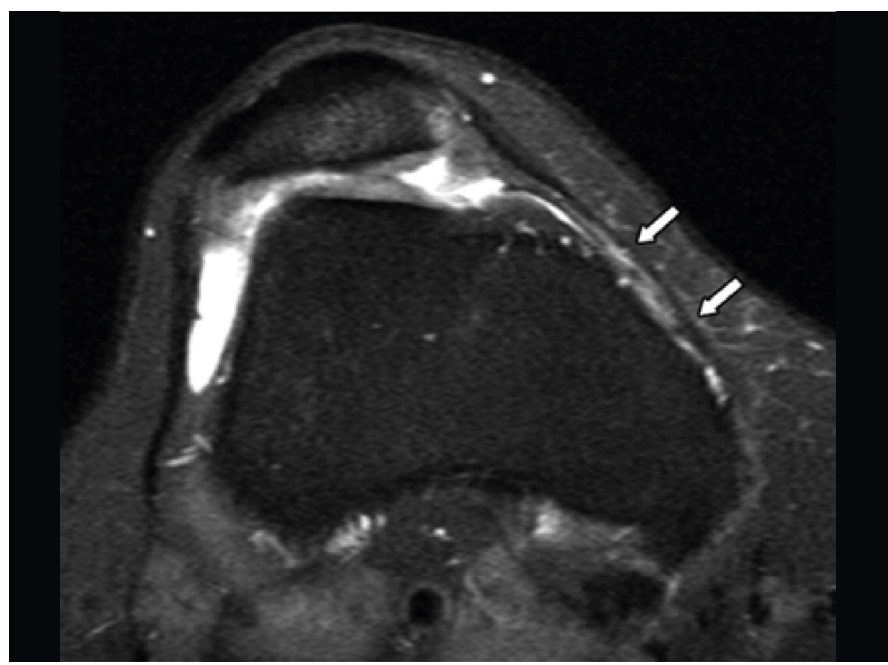

Figure 2. MRI image of grade 2 lesions of patellar cartilage.

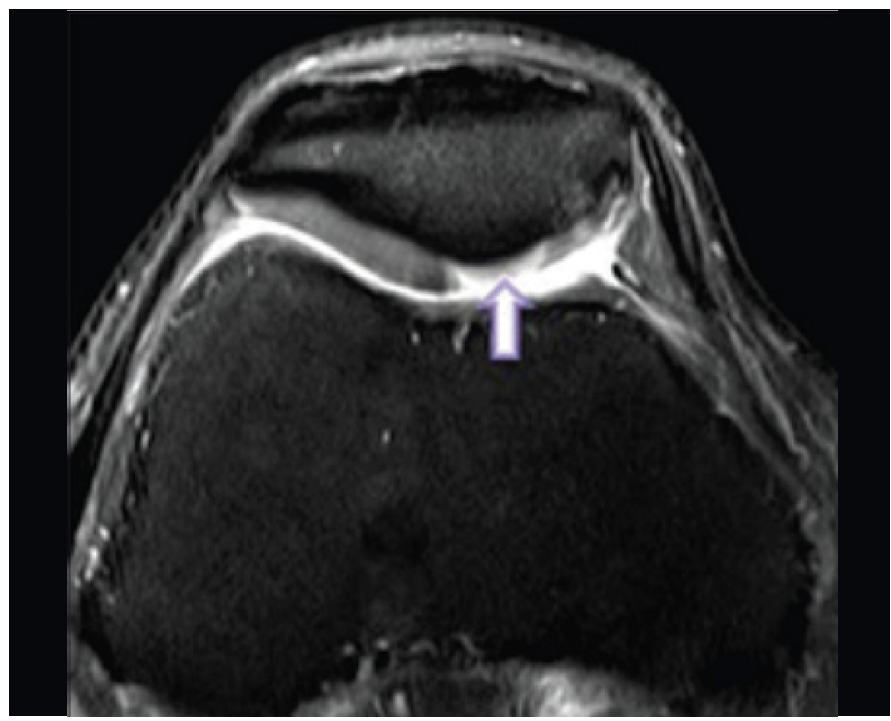

Figure 3. MRI image of grade 4 lesions of femoral cartilage.

\begin{tabular}{|c|c|c|c|c|c|c|}
\hline \multirow{2}{*}{$\begin{array}{c}\text { MRI classification } \\
\text { 3D-SPGR }\end{array}$} & \multicolumn{5}{|c|}{ Surgery } & \multirow{2}{*}{ Tota } \\
\hline & Level 0 & Level 1 & Level 2 & Level 3 & Level 4 & \\
\hline Level 0 & $84^{*}$ & 8 & 13 & 0 & 0 & 105 \\
\hline Level 1 & 42 & $32^{*}$ & 10 & 1 & 0 & 85 \\
\hline level 2 & 31 & 14 & $22^{*}$ & 2 & 1 & 70 \\
\hline Level 3 & 1 & 1 & 2 & $3^{*}$ & 2 & 9 \\
\hline level 4 & 0 & 0 & 0 & 1 & $6^{*}$ & 7 \\
\hline total & 158 & 55 & 47 & 7 & 9 & 276 \\
\hline \multicolumn{7}{|l|}{ 3D-FIESTA } \\
\hline Level 0 & $79 *$ & 2 & 7 & 0 & 0 & 88 \\
\hline Level 1 & 46 & $47^{*}$ & 12 & 1 & 0 & 106 \\
\hline level 2 & 33 & 5 & $27^{*}$ & 2 & 0 & 67 \\
\hline Level 3 & 0 & 1 & 1 & $4^{*}$ & 0 & 6 \\
\hline level 4 & 0 & 0 & 0 & 0 & $9^{*}$ & 9 \\
\hline total & 158 & 55 & 47 & 7 & 9 & 276 \\
\hline \multicolumn{7}{|l|}{$\begin{array}{c}\text { 3D-SPGR } \\
\text { combined with } \\
\text { conventional MRI }\end{array}$} \\
\hline $\begin{array}{c}\text { Level } 0 \\
\end{array}$ & $141^{*}$ & 5 & 2 & 0 & 0 & 148 \\
\hline Level 1 & 14 & $41^{*}$ & 8 & 0 & 0 & 63 \\
\hline level 2 & 3 & 9 & $37^{*}$ & 0 & 0 & 49 \\
\hline Level 3 & 0 & 0 & 0 & $7^{*}$ & 0 & 7 \\
\hline level 4 & 0 & 0 & 0 & 0 & $9^{*}$ & 9 \\
\hline
\end{tabular}

Table 1. Comparison of MRI classification and surgical diagnosis results.

Note: The data in the table is the number of cartilage articular surface classification statistics. *Means that the surgical grade is entirely consistent with the MRI grade. 
Table 2. Diagnostic results of each scan sequence.

\begin{tabular}{|c|c|c|c|c|c|c|c|}
\hline Sequence & True positive * & False-positive* & True negative ${ }^{*}$ & False-negative* & Sensitivity (\%) $\star$ & Specificity (\%) $\star$ & Accuracy (\%) \\
\hline \multicolumn{8}{|c|}{ 3D-SPGR } \\
\hline MFC & 13 & 5 & 24 & 4 & $76(68,89)$ & $83(72,95)$ & 80 \\
\hline MTP & 10 & 3 & 30 & 3 & $77(65,88)$ & $91(85,97)$ & 87 \\
\hline Trochlea & 8 & 3 & 32 & 3 & $73(62,89)$ & $91(87,97)$ & 87 \\
\hline Patela & 13 & 4 & 21 & 8 & $62(57,80)$ & $84(78,94)$ & 74 \\
\hline LFC & 10 & 1 & 24 & 11 & $48(29,56)$ & $96(84,98)$ & 74 \\
\hline MFC & 12 & 1 & 21 & 12 & $50(41,66)$ & $95(76,97)$ & 72 \\
\hline LTP & 8 & 5 & 26 & 7 & $53(42,68)$ & $84(71,92)$ & 74 \\
\hline MTP & 10 & 5 & 24 & 7 & $59(44,70)$ & $83(74,90)$ & 74 \\
\hline Trochlea & 8 & 5 & 26 & 7 & $53(38,67)$ & $84(75,92)$ & 74 \\
\hline Patela & 13 & 4 & 22 & 7 & $65(49,74)$ & $85(79,91)$ & 76 \\
\hline LTP & 5 & 0 & 38 & 3 & $63(54,77)$ & $100(77,100)$ & 93 \\
\hline MTP & 9 & 0 & 32 & 5 & $64(56,78)$ & $100(74,100)$ & 89 \\
\hline Trochlea & 8 & 1 & 36 & 1 & $89(74,95)$ & $97(84,99)$ & 96 \\
\hline Patela & 13 & 1 & 27 & 5 & $72(69,88)$ & $96(78,98)$ & 87 \\
\hline total & 57 & 3 & 195 & 21 & $73(64,89)$ & $98(79,99)$ & 91 \\
\hline
\end{tabular}

Note: *The data in the table represents the number of cartilage articular surface classification statistics. $\star$ The data in brackets represent the $95 \%$ confidence interval.

Table 3. Comparison of results of each sequence with surgical results.

\begin{tabular}{c|c|c|c}
\hline MRI sequence & 3D-SPGR & 3D-FIESTA & $\begin{array}{c}\text { 3D-SPGR } \\
\text { combined with } \\
\text { conventional MRI }\end{array}$ \\
\hline True positive & 63 & 61 & 57 \\
\hline False positive & 23 & 21 & 3 \\
\hline True negative & 160 & 143 & 195 \\
\hline False negative & 30 & 51 & 21 \\
\hline $\begin{array}{c}\text { Positive predictive } \\
\text { value (\%) }\end{array}$ & $73(63 / 86)$ & $74(61 / 82)$ & $95(57 / 60)$ \\
\hline $\begin{array}{c}\text { Negative predictive } \\
\text { value (\%) }\end{array}$ & $84(160 / 190)$ & $74(143 / 194)$ & $90(195 / 216)$ \\
\hline Sensitivity (\%) & $68(63 / 93)$ & $54(61 / 112)$ & $73(57 / 78)$ \\
\hline Specificity (\%) & $87(160 / 183)$ & $87(143 / 164)$ & $98(195 / 198)$ \\
\hline
\end{tabular}

\section{DISCUSSION}

The structure and function of articular cartilage are complex, and small trauma may cause its damage. ${ }^{10}$

This experiment shows that 3D SPGR sequence imaging can more accurately evaluate knee cartilage lesions with a sensitivity of $64 \%$, the specificity of $87 \%$, and accuracy of $80 \% .^{11}$
In this study, 3D FIESTA images showed a high agreement rate (60\%) between the diagnosis of knee hyaline cartilage lesions and surgical results; the sensitivity and specificity were $54 \%$ and $87 \%$.

When combining 3D SPGR and conventional MRI sequences in the diagnosis of cartilage lesions, the sensitivity and specificity of the paper are $73 \%$ and $98 \%$, respectively, and the positive and negative predictive values are $95 \%$ and $90 \%$, respectively, which are similar to the use of 3D SPGR or 3D FIESTA sequence alone. ${ }^{12}$

\section{CONCLUSION}

In summary, the results of 3D SPGR and 3D FIESTA sequences in diagnosing cartilage lesions are similar. By appropriately reducing NEX, the former's imaging time can be shortened to a reasonable range for clinical application. The thesis combines the 3D SPGR technology with the conventional MRI sequence of the knee joint, which can make a more accurate diagnosis of cartilage and make a more comprehensive evaluation of other tissue structures in the knee joint.

All authors declare no potential conflict of interest related to this article

AUTHORS' CONTRIBUTIONS: Each author made a significant personal contribution to the manuscript. Nai Liu analyzed and explained the data related to medical images. Bi-chuan Liu performed a histological examination of the Kwon3D software's knee sports injury classification and was the main contributor to the manuscript. Final manuscript read and approved by all authors.

\section{REFERENCES}

1. Wang $B$, Wang $L$, Wang $Y$, Qin F. Clinical diagnostic value of magnetic resonance imaging in knee joint sports injury. Journal of Medical Imaging and Health Informatics. 2021;11(2):453-61.

2. Kosy JD, Matteliano L, Rastogi A, Pearce D, Whelan DB. Meniscal root tears occur frequently in multi-ligament knee injury and can be predicted by associated MRI injury patterns. Knee Surg Sports Traumatol Arthrosc. 2018;26(12):3731-7.

3. Macdonald B, McAleer S, Kelly S, Chakraverty R, Johnston M, Pollock N. Hamstring rehabilitation in elite track and field athletes: applying the British Athletics Muscle Injury Classification in clinical practice. Br J Sports Med. 2019;53(23):1464-73.

4. Whittaker JL, Toomey CM, Woodhouse LJ, Jaremko JL, Nettel-Aguirre A, Emery CA. Association between MRI-defined osteoarthritis, pain, function and strength 3-10 years following knee joint injury in youth sport. Br J Sports Med. 2018;52(14):934-9.

5. Zhang C, Xie G, Dong S, Chen C, Peng X, Yuan F, et al. A novel morphological classification for the femoral notch based on MRI: a simple and effective assessment method for the femoral notch. Skeletal Radiol. 2020;49(1):75-83.

6. Ekås GR, Laane MM, Larmo A, Moksnes H, Grindem H, Risberg MA, et al. Knee pathology in young adults after pediatric anterior cruciate ligament injury: a prospective case series of 47 patients with a mean 9.5-year follow-up. Am J Sports Med. 2019;47(7):1557-66.
7. Lundblad M, Hägglund M, Thomeé C, Hamrin Senorski E, Ekstrand J, Karlsson J, et al. Medial collateral ligament injuries of the knee in male professional football players: a prospective three-season study of 130 cases from the UEFA Elite Club Injury Study. Knee Surg Sports Traumatol Arthrosc. 2019;27(11):3692-8.

8. Green D, Tuca M, Luderowski E, Gausden E, Goodbody C, Konin G. A new, MRI-based classification system for tibial spine fractures changes clinical treatment recommendations when compared to Myers and Mckeever. Knee Surg Sports Traumatol Arthrosc. 2019;27(1):86-92.

9. Szopinski KT, Adamczyk P. Interposition of the transverse ligament of the knee into a fracture of the tibial plateau: a case report. Skeletal Radiol. 2018;47(7):1011-4.

10. Wood D, French SR, Munir S, Kaila R. The surgical repair of proximal hamstring avulsions. Bone Joint J. 2020;102-B(10):1419-27.

11. Ockuly AC, Imada AO, Richter DL, Treme GP, Wascher DC, Schenck RC Jr; "UNMKD Recon Group". Initial Evaluation and Classification of Knee Dislocations. Sports Med Arthrosc Rev. 2020;28(3):87-93.

12. Greif DN, Baraga MG, Rizzo MG, Mohile NV, Silva FD, Fox T, Jose J. MRI appearance of the different meniscal ramp lesion types, with clinical and arthroscopic correlation. Skeletal Radiol. 2020;49(5):677-689. 